$\xi^{2}=-1$

\title{
Direct plant regeneration through micropropagation using selected explants of sugarcane
}

\author{
Purnendu Biswas ${ }^{1 *}$, Md. Harun-Or-Rashid ${ }^{1}$, Abul Kashem Chowdhury ${ }^{2}$, Md. Amzad Hossain ${ }^{4}$ \\ ${ }^{1}$ Professor, Department of Agronomy, Patuakhali Science and Technology University, Patuakhali, Bangladesh \\ 2 Professor, Department of Genetics and Plant Breeding, Patuakhali Science and Technology University, Patuakhali, Bangladesh \\ ${ }^{3}$ Chief Scientific Officer, Biotechnology Division, Bangladesh Sugarcrop Research Institute, Pabna, Bangladesh \\ *Corresponding author E-mail: purnendu@pstu.ac.bd
}

\begin{abstract}
The experiment was conducted at the Laboratory of Biotechnology Division, Bangladesh Sugarcrop Research Institute (BSRI), Ishurdi, Pabna during the period from January 2009 to December 2009 to regenerate plants through micropropagation technique using selected explants of sugarcane. In this experiment shoot tip, leaf segment and leaf roll section explants of three sugarcane varieties (Isd 16, Isd 35 and Isd 36) were cultured on shoot inducing MS media with four combinations of NAA and Kn (NAA2.5Kn0.5, NAA5.0Kn0.5, NAA7.5Kn0.5 and NAA10.0Kn0.5 mg/l) to regenerate plants. The proliferated shoots were multiplied on liquid MS media with five combinations of BAP and $\mathrm{Kn}$ (BAP0.25Kn0.25, BAP0.5Kn0.25, BAP0.5Kn0.5, BAP1.0Kn0.5 and BAP1.0Kn1.0 mg/l) and further transferred to root inducing MS media fortified with six different concentrations of NAA $(1.0,2.0,3.0,4.0,5.0$ and $6.0 \mathrm{mg} / \mathrm{l})$ for adventitious root formation to raise full-fledged plantlets. The leaf roll section explant of variety Isd 35 cultured on MS medium containing hormonal combination of $7.5 \mathrm{mg} / \mathrm{l} \mathrm{NAA}+0.5 \mathrm{mg} / \mathrm{l} \mathrm{Kn}$ produced the highest percentage $(83.33 \%)$ of shoot regeneration. The number of shoots per explant was also found highest (10.23) in the same explant of same variety with the same hormonal combination. The highest multiplication rate (4.64) was obtained from the liquid MS medium containing hormonal combination of $1.0 \mathrm{mg} / \mathrm{l} \mathrm{BAP}+0.5 \mathrm{mg} / \mathrm{l} \mathrm{Kn}$ in the variety Isd 35. The MS medium containing $5.0 \mathrm{mg} / \mathrm{l}$ NAA showed better performance for adventitious root induction to raise fullfledged plantlets in all the varieties within nine days of inoculation.
\end{abstract}

Keywords: Sugarcane; Plant Regeneration; Micropropagation; Explants.

\section{Introduction}

Sugarcane is an important cash-cum-industrial crop in Bangladesh and the main raw materials for sugar industries. It also used for gur and juice production and with the pace of population growth the demand of sugar, gur and juice is increasing tremendously. However, due to higher demand or production of vegetables, pulses etc. the acreage of sugarcane is decreasing and gradually being pushed to low lying marginal lands prone to water-logging, salinity and drought stresses. Hence, the overall production of sugarcane for meeting the increasing demand of sugar and gur of the growing people is not increasing. Therefore, it is very urgent to increase the cane productivity without further area expansion to meet the future need of sugar and gur in Bangladesh.

Conventional propagation of sugarcane through offsets is slow, usually one to ten in a period of one year. Moreover, pathogens keep on accumulation generation after generation, which reduces the yield and quality of sugarcane. Therefore, efficient propagation system is required for mass multiplication of sugarcane varieties. Micropropagation through tissue culture holds great potential for mass multiplication and subsequent rejuvenation and quality production of sugarcane (Sood et al. 2006). Newly released variety becomes abandoned and deteriorates by the attack of systemic diseases during long expansion time before utilization of potential productivity. At this point, micropropagation poses a potential role in promoting readily available planting materials of newly-released high-yielding varieties for productivity improvement of sugarcane. To explore the potential productivity and to combat deterioration, micropropagation could be used for rapid propagation and expansion of sugarcane within a shorter period of time. Since micropropagation is carried out under microbe free laboratory conditions throughout the year, disease free planting stocks can be produced by shoot tip or leaf segment or leaf roll section culture. Researchers from other countries have shown that planting materials developed through micropropagation increased the productivity of sugarcane about 13\% over conventional planting (Ramon and Federico, 2002). In Bangladesh there is a scope to produce large-scale high quality seedlings (seeds) through micropropagation for increasing sugarcane yield. Therefore, the present research work is designed to regenerate plants through micropropagation technique.

\section{Materials and methods}

The experiment was conducted at the Laboratory of Biotechnology Division, Bangladesh Sugarcrop Research Institute (BSRI), Ishurdi, Pabna during the period from January 2009 to December 2009 to regenerate plants through micropropagation technique using selected 
explants of sugarcane. The experiment was laid out in Completely Randomized Design (CRD) with three replications (each replication contains ten cultures) in the Laboratory. The young shoot top of 4-8 month old field grown sugarcane varieties (Isd 16, Isd 35 and Isd 36) were used as the source of explants in the experiment. After removing the outer additional leaves, the shoot tops were thoroughly washed under aseptic conditions. The immature leaf rolls were formed by the innermost 5-6 tightly furled spindle leaves. Then shoot tips, leaf roll segments (approximately $0.5 \mathrm{~cm}$ ) and leaf roll sections (about 1-2 mm thick) were prepared as explants. The Explants were prepared on the laminar airflow cabinet aseptically from the sterilized leaf sheaths using a fine sterile forceps and scalpel. The excised explants were then inoculated into each culture test tube containing solid MS media with four combinations of NAA and $\mathrm{Kn}_{2}\left(\mathrm{NAA}_{2.5} \mathrm{Kn}_{0.5}\right.$, $\mathrm{NAA}_{5.0} \mathrm{Kn}_{0.5}, \mathrm{NAA}_{7.5} \mathrm{Kn}_{0.5}$ and $\left.\mathrm{NAA}_{10.0} \mathrm{Kn}_{0.5} \mathrm{mg} / \mathrm{l}\right)$ for direct plants regeneration. Subcultures were carried out regularly at an interval of 4-5 weeks for further shoot multiplication on liquid MS media with five different hormonal combinations specified for shoot multiplication $\left(\mathrm{BAP}_{0.25} \mathrm{Kn}_{0.25}, \mathrm{BAP}_{0.5} \mathrm{Kn}_{0.25}, \mathrm{BAP}_{0.5} \mathrm{Kn}_{0.5}, \mathrm{BAP}_{1.0} \mathrm{Kn}_{0.5}\right.$ and $\left.\mathrm{BAP}_{1.0} \mathrm{Kn}_{1.0} \mathrm{mg} / \mathrm{l}\right)$ which was different from the establishment stage. The regenerated mini shoots of three sugarcane varieties were cultured on MS media supplemented with six different concentrations of NAA $(1.0,2.0,3.0,4.0,5.0$ and $6.0 \mathrm{mg} / \mathrm{l})$ individually for root formation. All the cultured vessels were incubated in a temperature controlled growth room $\left(25 \pm 1^{\circ} \mathrm{C}\right)$ of 16 hours photoperiod maintained with illuminated fluorescent tube of 2000-3000 lux. The regenerated rooted plants were brought out from the culture media and the root system of the plants was made to agar gel free by continuous flowing of tap water and kept for about 2 hours to remove any remains of sucrose and agar. Then the plants were transferred on to soil mix ( 3 parts soil: 1 part well decomposed saw dust) in polythene bag $(12.5 \mathrm{~cm} \times 10.0 \mathrm{~cm})$. Then polythene bags with plants were kept under polythene shade with high moisture for 2 weeks acclimatization. Data on shoot induction, shoot multiplication and root induction were recorded at 30 days after inoculation in each case.

\section{Results and discussion}

\subsection{Shoot induction}

It was observed that days to shoot initiation, percentage of regenerated explant, number of shoots per explant and shoot length differed among the varieties, types of explants and hormonal combinations (Table 1, 2, 3 and 4). The highest percentage of regenerated explants $(55.56 \%)$ was obtained from the variety Isd 35 because of early shoot formation (20.78 days) in the variety. The highest number of shoots $(7.65)$ and shoot length per explants $(6.78 \mathrm{~cm})$ was also found in the variety Isd 35 . This might be due to early shoot regeneration in the variety Isd 35 than other varieties. The shoot tip explants produced shoot earlier (20.19 days), because shoot proliferation was occurred from nodes where leaf base was adjacent to the stem. But in leaf segment or leaf roll section explant, adventitious shoot proliferation was occurred from cut ends. So, shoot proliferation was found earlier in shoot tip explants than other explants. The highest percentage of regenerated explants $(64.17 \%)$ and shoots per explants $(8.54)$ was found in leaf roll section explants. The highest shoots in leaf roll section might be due to higher space available in the cut ends of the explants for shoot regeneration. But the leaf segment explants produced highest shoot length per explant $(7.61 \mathrm{~cm})$. The highest days to shoot initiation $(22.73)$ were recorded in shooting media 2.5 $\mathrm{mg} / \mathrm{l} \mathrm{NAA}+0.5 \mathrm{mg} / \mathrm{l} \mathrm{Kn}$ due to the interaction effects of auxin and cytokinin. In addition, there was an evident from the previous study that folded leaf explants did not response shooting in the media containing single hormone but in combination of cytokinin or combination of cytokinin and auxin produced numerous shoots within shortest period of time. The highest percentage of regenerated explant $(58.89 \%)$ was observed in $7.5 \mathrm{mg} / \mathrm{l} \mathrm{NAA}+0.5 \mathrm{mg} / \mathrm{l} \mathrm{Kn}$. Gill et al. (2006) reported that the highest frequency (83.12\%) of shoot regeneration occurred on MS medium supplemented with $5.0 \mathrm{mg} / \mathrm{l} \mathrm{NAA}$ and $0.5 \mathrm{mg} / \mathrm{l} \mathrm{Kn}$. They also reported that elevated concentration of NAA $(10.0 \mathrm{mg} / \mathrm{l})$ caused little callusing at the cut ends of explants and thus reduced the percent shoot regeneration. Therefore, it was noted that addition of auxin (NAA) was necessary for induction of direct shoot regeneration but increase concentration of NAA reduced the percentage of plant regeneration. The hormonal combination of $7.5 \mathrm{mg} / \mathrm{l} \mathrm{NAA}$ and $0.5 \mathrm{mg} / \mathrm{l} \mathrm{Kn}$ showed the highest number of shoots (7.51) and shoot length per explants $(7.04 \mathrm{~cm})$. This might be due to the early shoot initiation. Gupta and Bhatia (2004) reported that among the various media composition, MS media supplemented with $5.0 \mathrm{mg} / \mathrm{l} \mathrm{NAA}$ and $0.5 \mathrm{mg} / \mathrm{K} \mathrm{n}$ was found to induce high frequency direct shoot regeneration. The interaction effect showed that the shoot tip explants of variety Isd 16 with shooting media $7.5 \mathrm{mg} / \mathrm{l} \mathrm{NAA}+$ $0.5 \mathrm{mg} / \mathrm{l} \mathrm{Kn}$ exhibited the lowest days to shoot initiation (18.27) because of lowest value found in shoot tip explants with shooting media $7.5 \mathrm{mg} / \mathrm{l} \mathrm{NAA}+0.5 \mathrm{mg} / \mathrm{l}$. The highest percentage of regenerated explant $(83.33 \%)$ was observed in leaf roll section explants of variety Isd 35 with $7.5 \mathrm{mg} / \mathrm{l} \mathrm{NAA}+0.5 \mathrm{mg} / 1 \mathrm{Kn}$. This might be due to the highest percentage of regenerated explant in leaf roll section explants and shooting media $7.5 \mathrm{mg} / \mathrm{l}+0.5 \mathrm{mg} / \mathrm{l}$ individually. The highest number of shoots per explant (10.23) was recorded in leaf roll section explants of variety Isd 35 with hormonal combination of $7.5 \mathrm{mg} / \mathrm{l} \mathrm{NAA}$ and $0.5 \mathrm{mg} / \mathrm{l} \mathrm{Kn}$. The highest shoot length $(8.86 \mathrm{~cm})$ was obtained in leaf segment explants of variety Isd 35 with hormonal combination of $7.5 \mathrm{mg} / \mathrm{l} \mathrm{NAA}$ and $0.5 \mathrm{mg} / \mathrm{l} \mathrm{Kn}$.

Table 1: Effect of Varieties on Shoot Initiation

\begin{tabular}{lllll}
\hline Varieties & Days to shoot initiation & $\begin{array}{l}\text { Percentage of regenerated } \\
\text { explant }\end{array}$ & Number of shoots/explant & $\begin{array}{l}\text { Shoot length/ ex- } \\
\text { plants (cm) }\end{array}$ \\
\hline Isd 16 & $21.30 \mathrm{~b}$ & $41.11 \mathrm{c}$ & $6.24 \mathrm{c}$ & $6.25 \mathrm{~b}$ \\
Isd 35 & $20.78 \mathrm{~b}$ & $55.56 \mathrm{a}$ & $7.65 \mathrm{a}$ & $6.78 \mathrm{a}$ \\
Isd 36 & $22.94 \mathrm{a}$ & $50.00 \mathrm{~b}$ & $6.83 \mathrm{~b}$ & $6.44 \mathrm{~b}$ \\
$\mathrm{~S}_{\overline{\mathrm{x}}}$ & 0.370 & 1.293 & 0.123 & 0.105 \\
CV $(\%)$ & 10.24 & 19.95 & 12.50 & 13.99 \\
\hline
\end{tabular}

Table 2: Effect of Explants on Shoot Initiation

\begin{tabular}{lllll}
\hline Explants & Days to shoot initiation & Percentage of regenerated explant & Number of shoots/explant & Shoot length/ explants (cm) \\
\hline Shoot tip & $20.19 \mathrm{~b}$ & $34.72 \mathrm{c}$ & $4.64 \mathrm{c}$ & $6.27 \mathrm{~b}$ \\
Leaf segment & $22.09 \mathrm{a}$ & $47.78 \mathrm{~b}$ & $7.54 \mathrm{~b}$ & $7.61 \mathrm{a}$ \\
Leaf roll section & $22.74 \mathrm{a}$ & $64.17 \mathrm{a}$ & $8.54 \mathrm{a}$ & $5.59 \mathrm{c}$ \\
$\mathrm{S}_{\overline{\mathrm{x}}}$ & 0.370 & 1.293 & 0.123 & 0.105 \\
$\mathrm{CV}(\%)$ & 10.24 & 19.95 & 12.50 & 13.99 \\
\hline
\end{tabular}

Table 3: Effect of Different Hormonal Combinations of NAA and Kn on Shoot Initiation

\begin{tabular}{llll}
\hline Treatments & Days to shoot initiation & $\begin{array}{l}\text { Percentage of regenerated } \\
\text { explant }\end{array}$ & $\begin{array}{l}\text { Number of shoots/explant } \\
\text { explants (cm) }\end{array}$ \\
\hline NAA $_{2.5} \mathrm{Kn}_{0.5} \mathrm{mg} / \mathrm{l}$ & $22.73 \mathrm{a}$ & $36.30 \mathrm{~d}$ & $6.13 \mathrm{c}$
\end{tabular}




\begin{tabular}{llll}
$\mathrm{NAA}_{5.0} \mathrm{Kn}_{0.5} \mathrm{mg} / \mathrm{l}$ & $21.21 \mathrm{~b}$ & $54.07 \mathrm{~b}$ & $7.07 \mathrm{~b}$ \\
$\mathrm{NAA}_{7.5} \mathrm{Kn}_{0.5} \mathrm{mg} / \mathrm{l}$ & $21.16 \mathrm{~b}$ & $58.89 \mathrm{a}$ & $7.51 \mathrm{a}$ \\
$\mathrm{NAA}_{10.0} \mathrm{Kn}_{0.5} \mathrm{mg} / \mathrm{l}$ & $21.60 \mathrm{ab}$ & $46.30 \mathrm{c}$ & $6.89 \mathrm{~b}$ \\
$\mathrm{~S}_{\overline{\mathrm{x}}}$ & 0.641 & 2.240 & 0.213 \\
$\mathrm{CV}(\%)$ & 10.24 & 19.95 & $12.04 \mathrm{a}$ \\
\hline
\end{tabular}

Table 4: Interaction Effect of Varieties, Explants and Hormonal Combinations of NAA and Kn on Shoot Initiation

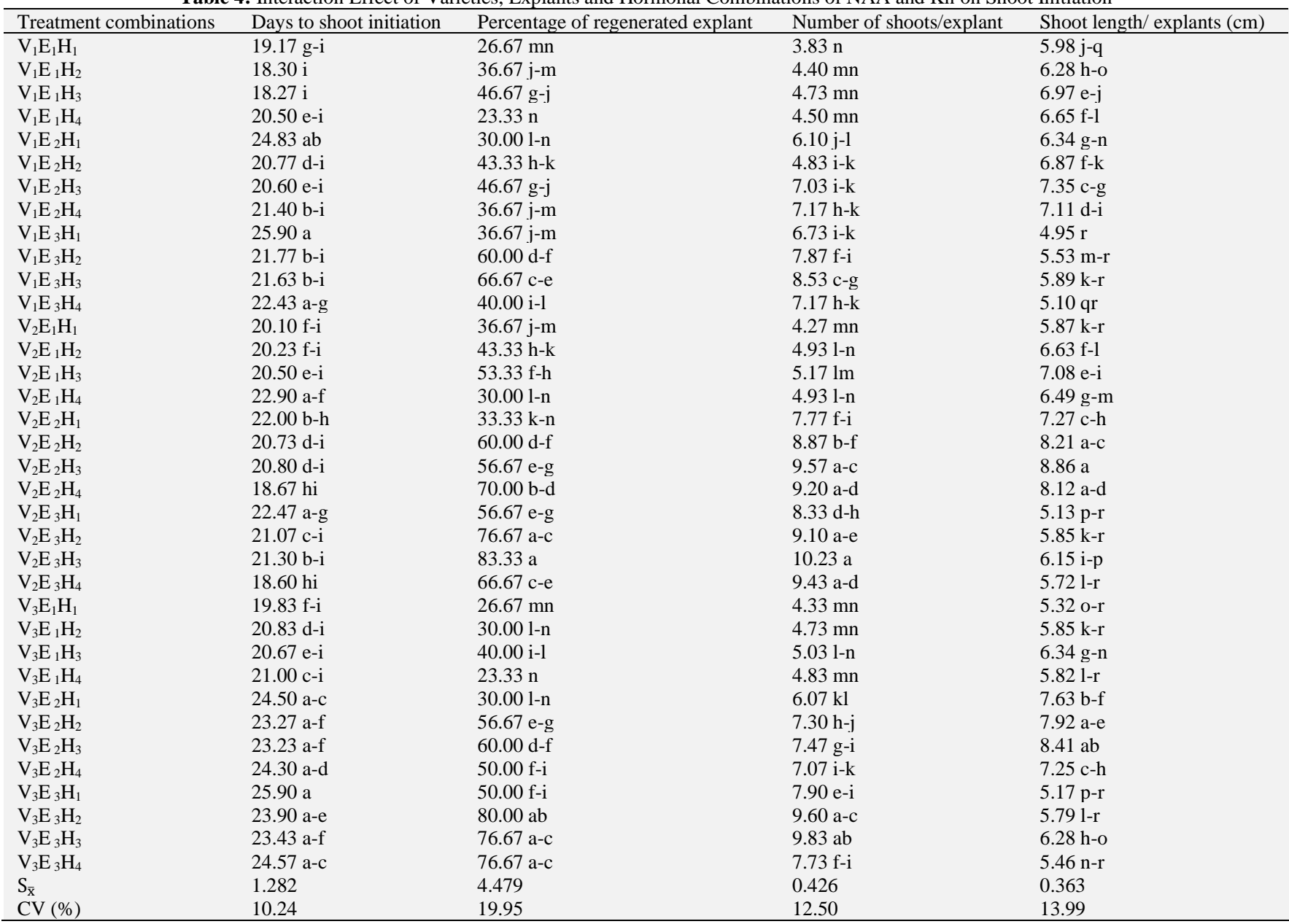

$\mathrm{V}_{1}=$ Isd 16, $\mathrm{V}_{2}=$ Isd $35, \mathrm{~V}_{3}=$ Isd 36

$\mathrm{E}_{1}=$ Shoot tip, $\mathrm{E}_{2}=$ Leaf segment, $\mathrm{E}_{3}=$ Leaf roll section.

$\mathrm{H}_{1}=\mathrm{NAA}_{2.5} \mathrm{Kn}_{0.5}, \mathrm{H}_{2}=\mathrm{NAA}_{5.0} \mathrm{Kn}_{0.5}, \mathrm{H}_{3}=\mathrm{NAA}_{7.5} \mathrm{Kn}_{0.5}, \mathrm{H}_{4}=\mathrm{NAA}_{10.0} \mathrm{Kn}_{0.5} \mathrm{mg} / \mathrm{l}$.

\subsection{Shoot multiplication}

The highest rate of shoot multiplication (4.64) was observed in variety Isd 35 with hormonal combination of $1.0 \mathrm{mg} / \mathrm{l} \mathrm{BAP}+0.5 \mathrm{mg} / \mathrm{Kn}$ whereas the lowest rate (3.23) was found in variety Isd 36 with hormonal combination of $0.25 \mathrm{mg} / \mathrm{l} \mathrm{BAP}+0.25 \mathrm{mg} / \mathrm{l} \mathrm{Kn}$ (Table 5). These results indicate that the variety Isd 35 was the best for increasing shoot number from a single shoot.

Table 5: Shoot Multiplication of Sugarcane Varieties Affected by Hormonal Combinations of BAP and Kn

\begin{tabular}{llll}
\hline Treatments & Isd 16 & Isd 35 & Isd 36 \\
\hline BAP $_{0.25} \mathrm{Kn}_{0.25}$ & $3.39 \mathrm{fg}$ & $3.46 \mathrm{fg}$ & $3.23 \mathrm{~g}$ \\
$\mathrm{BAP}_{0.5} \mathrm{Kn}_{0.25}$ & $3.46 \mathrm{fg}$ & $3.88 \mathrm{de}$ & $3.61 \mathrm{ef}$ \\
$\mathrm{BAP}_{0.5} \mathrm{Kn}_{0.5}$ & $3.63 \mathrm{ef}$ & $4.22 \mathrm{bc}$ & $4.04 \mathrm{~cd}$ \\
$\mathrm{BAP}_{1.0} \mathrm{Kn}_{0.5}$ & $4.31 \mathrm{bc}$ & $4.64 \mathrm{a}$ & $4.39 \mathrm{ab}$ \\
$\mathrm{BAP}_{1.0} \mathrm{Kn}_{1.0}$ & $4.02 \mathrm{~cd}$ & $4.11 \mathrm{bcd}$ & $4.12 \mathrm{bcd}$ \\
\hline
\end{tabular}

\subsection{Root Induction}

The effect of varieties and concentrations of NAA on days to root initiation, number of roots and root length was significant (Table 6, 7 and 8). The lowest days to root initiation (9.49) was found in variety Isd 35. The results might be due to the effect of varietal characteristics. Singh et al. (2001) evaluated sugarcane cultivars Co 89003, CoJ 83, CoJ 85, CoJ 86 and CoS 95255 and reported that fine roots began to develop from basal portion of shoots after 7-15 days of inoculation which ranged from 75\% (CoJ 85) to 95\% (CoJ 86) in different cultivars. They also reported that the number of days taken for rooting varied from variety to variety but profuse rooting was achieved within 30-40 days. The highest number of roots per shoot (11.33) and root length per shoot (1.79 cm) was obtained from the variety Isd 35 due to early root initiation than other varieties. Cheema and Hussain (2004) cultured sugarcane varieties and found maximum root length $(3.20 \mathrm{~cm})$ in variety SPF 213 after 30 days and minimum root length $(0.43 \mathrm{~cm})$ in variety CP 77400 . On the other hand, there was a decreasing trend of days to root initiation with the increasing of the concentration of NAA. The lowest days to root initiation (8.76) was found in $5.0 \mathrm{mg} / \mathrm{l} \mathrm{NAA}$. But a higher days to root initiation was found in $6.0 \mathrm{mg} / \mathrm{l}$ NAA. This might be due to inhibition of rooting at 
higher concentration of NAA because it inhibits the root induction and elongation. The highest number of roots per shoot (11.70) and root length per shoot $(1.90 \mathrm{~cm})$ was found in $5.0 \mathrm{mg} / 1$ NAA due to the early root initiation. These results are in agreement with the findings of Shukla et al. (1994) who reported that maximum number of roots was obtained in the medium containing $5.0 \mathrm{mg} / \mathrm{l}$ NAA but more than $5.0 \mathrm{mg} / \mathrm{l} \mathrm{NAA}$ inhibits rooting. The interaction effect showed that all the varieties gave the best result with rooting media $5.0 \mathrm{mg} / \mathrm{l}$ NAA than other treatments among them variety Isd 35 ranked the lowest (8.23). Singh et al. (2001) transferred a small clump with 5-10 well grown shoots of different cultivars on $1 / 2 \mathrm{MS}$ liquid rooting medium supplemented with $5.0 \mathrm{mg} / \mathrm{l}$ NAA and found to develop fine roots after 7-15 days in different cultivars. The highest number of roots per shoot (13.70) and root length per shoot $(2.15 \mathrm{~cm})$ was also obtained from the variety Isd 35 with rooting media $5.0 \mathrm{mg} / \mathrm{l}$ NAA. Tarique et al. (2010) developed an efficient protocol for micropropagation of sugarcane using leaf sheath culture method of three sugarcane varieties viz. Isd 16, Isd 36 and Isd 37 and observed the best results of root formation on MS medium supplemented with $5.0 \mathrm{mg} / \mathrm{l} \mathrm{NAA}$. The lowest number of roots per shoot (6.87) was found in variety Isd 36 with rooting media $1.0 \mathrm{mg} / \mathrm{l}$ NAA followed by the same variety with rooting media $2.0 \mathrm{mg} / \mathrm{l}$ NAA (6.93) which was statistically similar.

Table 6: Effect of Varieties on in Vitro Rooting Potentiality

\begin{tabular}{llll}
\hline Varieties & Days to root initiation & Number of roots/shoot & Root length/ shoot (cm) \\
\hline Isd 16 & $10.31 \mathrm{~b}$ & $9.42 \mathrm{~b}$ & $1.56 \mathrm{~b}$ \\
Isd 35 & $9.49 \mathrm{c}$ & $11.33 \mathrm{a}$ & $1.79 \mathrm{a}$ \\
Isd 36 & $11.24 \mathrm{a}$ & $8.13 \mathrm{c}$ & $1.42 \mathrm{c}$ \\
$\mathrm{S}_{\overline{\mathrm{x}}}$ & 0.114 & 0.162 & 0.030 \\
$\mathrm{CV}(\%)$ & 4.66 & 7.14 & 7.96 \\
\hline
\end{tabular}

Table 7: Effect of Different Concentrations of NAA on in Vitro Rooting Potentiality

\begin{tabular}{llll}
\multicolumn{2}{c}{ Table 7: Effect of Different Concentrations of NAA on in Vitro Rooting Potentiality } \\
\hline Treatments & Days to root initiation & Number of roots/shoot & Root length/ shoot (cm) \\
\hline NAA $_{1.0} \mathrm{mg} / \mathrm{l}$ & $11.95 \mathrm{a}$ & $7.73 \mathrm{~d}$ & $1.24 \mathrm{e}$ \\
$\mathrm{NAA}_{2.0} \mathrm{mg} / \mathrm{l}$ & $11.48 \mathrm{a}$ & $8.32 \mathrm{~cd}$ & $1.37 \mathrm{~d}$ \\
$\mathrm{NAA}_{3.0} \mathrm{mg} / \mathrm{l}$ & $10.77 \mathrm{~b}$ & $8.92 \mathrm{c}$ & $1.54 \mathrm{c}$ \\
$\mathrm{NAA}_{4.0} \mathrm{mg} / 1$ & $9.80 \mathrm{c}$ & $10.00 \mathrm{~b}$ & $1.69 \mathrm{~b}$ \\
$\mathrm{NAA}_{5.0} \mathrm{mg} / 1$ & $8.76 \mathrm{~d}$ & $11.70 \mathrm{a}$ & $1.90 \mathrm{a}$ \\
$\mathrm{NAA}_{6.0} \mathrm{mg} / 1$ & $9.34 \mathrm{c}$ & $11.09 \mathrm{a}$ & $1.82 \mathrm{a}$ \\
$\mathrm{S}_{\overline{\mathrm{x}}}$ & 0.161 & 0.229 & 0.042 \\
$\mathrm{CV}(\%)$ & 4.66 & 7.14 & 7.96 \\
\hline
\end{tabular}

Table 8: Interaction Effect of Varieties and Different Concentrations of NAA on in Vitro Rooting Potentiality

\begin{tabular}{|c|c|c|c|}
\hline Treatment combinations & Days to root initiation & Number of roots/shoot & Root length/ shoot $(\mathrm{cm})$ \\
\hline Isd $16 \times \mathrm{NAA}_{1.0} \mathrm{mg} / \mathrm{l}$ & $11.80 \mathrm{bc}$ & $7.63 \mathrm{ij}$ & $1.23 \mathrm{j}-1$ \\
\hline Isd $16 \times \mathrm{NAA}_{2.0} \mathrm{mg} / \mathrm{l}$ & $11.30 \mathrm{~cd}$ & $8.20 \mathrm{hi}$ & $1.38 \mathrm{~h}-\mathrm{j}$ \\
\hline Isd $16 \times \mathrm{NAA}_{3.0} \mathrm{mg} / \mathrm{l}$ & $10.73 \mathrm{de}$ & 8.27 hi & $1.53 \mathrm{f}-\mathrm{i}$ \\
\hline Isd $16 \times \mathrm{NAA}_{5.0} \mathrm{mg} / \mathrm{l}$ & $8.63 \mathrm{i}$ & $11.80 \mathrm{~b}-\mathrm{d}$ & $1.83 \mathrm{~b}-\mathrm{d}$ \\
\hline Isd $16 \times \mathrm{NAA}_{6.0} \mathrm{mg} / \mathrm{l}$ & $9.50 \mathrm{~g}$ & $11.20 \mathrm{~cd}$ & $1.75 \mathrm{c}-\mathrm{e}$ \\
\hline Isd $35 \times \mathrm{NAA}_{1.0} \mathrm{mg} / \mathrm{l}$ & $11.17 \mathrm{~cd}$ & $8.70 \mathrm{f}-\mathrm{i}$ & $1.34 \mathrm{i}-1$ \\
\hline Isd $35 \times \mathrm{NAA}_{3.0} \mathrm{mg} / \mathrm{l}$ & $9.84 \mathrm{fg}$ & $10.83 \mathrm{de}$ & $1.72 \mathrm{~d}-\mathrm{f}$ \\
\hline Isd $35 \times \mathrm{NAA}_{4.0} \mathrm{mg} / \mathrm{l}$ & $8.70 \mathrm{hi}$ & $12.10 \mathrm{bc}$ & $1.93 \mathrm{bc}$ \\
\hline Isd $35 \times \mathrm{NAA}_{5.0} \mathrm{mg} / \mathrm{l}$ & $8.23 \mathrm{i}$ & $13.70 \mathrm{a}$ & $2.15 \mathrm{a}$ \\
\hline Isd $35 \times \mathrm{NAA}_{6.0} \mathrm{mg} / \mathrm{l}$ & $8.40 \mathrm{i}$ & $12.83 \mathrm{ab}$ & $2.03 \mathrm{ab}$ \\
\hline Isd $36 \times \mathrm{NAA}_{1.0} \mathrm{mg} / \mathrm{l}$ & $12.83 \mathrm{a}$ & $6.87 \mathrm{j}$ & 1.141 \\
\hline Isd $36 \times \mathrm{NAA}_{2.0} \mathrm{mg} / \mathrm{l}$ & $12.50 \mathrm{ab}$ & $6.93 \mathrm{j}$ & $1.16 \mathrm{kl}$ \\
\hline Isd $36 \times \mathrm{NAA}_{3.0} \mathrm{mg} / \mathrm{l}$ & $11.73 \mathrm{bc}$ & $7.69 \mathrm{ij}$ & $1.36 \mathrm{i}-\mathrm{k}$ \\
\hline Isd $36 \times \mathrm{NAA}_{4.0} \mathrm{mg} / \mathrm{l}$ & $10.80 \mathrm{de}$ & $8.47 \mathrm{~g}-\mathrm{i}$ & $1.50 \mathrm{~g}-\mathrm{i}$ \\
\hline Isd $36 \times \mathrm{NAA}_{6.0} \mathrm{mg} / \mathrm{l}$ & $10.13 \mathrm{e}-\mathrm{g}$ & $9.23 \mathrm{f}-\mathrm{h}$ & $1.68 \mathrm{~d}-\mathrm{g}$ \\
\hline $\mathrm{S}_{\overline{\mathrm{x}}}$ & 0.279 & 0.397 & 0.073 \\
\hline $\mathrm{CV}(\%)$ & 4.66 & 7.14 & 7.96 \\
\hline
\end{tabular}

\section{Conclusion}

The results showed that variety Isd 35 required lowest days to shoot initiation than other varieties. The percentage of regenerated explant, number of shoots and shoot length was found highest in variety Isd 35. On the other hand, shoot tip explant required lowest days to shoot initiation. The percentage of regenerated explant and number of shoots was found highest in leaf roll section explants. But the highest shoot length was obtained from leaf segment explants. It was shown that the lowest days to shoot initiation were recorded in shooting media $7.5 \mathrm{mg} / \mathrm{l} \mathrm{NAA}+0.5 \mathrm{mg} / \mathrm{Kn}$. The highest percentage of regenerated explant, number of shoots and shoot length was also found in shooting media $7.5 \mathrm{mg} / \mathrm{l} \mathrm{NAA}+0.5 \mathrm{mg} / \mathrm{Kn}$. On the other hand, shoot tip explants with shooting media $7.5 \mathrm{mg} / \mathrm{l} \mathrm{NAA}+0.5 \mathrm{mg} / \mathrm{l} \mathrm{Kn}$ of variety Isd 16 exhibited lowest days to shoot initiation. The percentage of regenerated explant and number of shoots per explant was found highest in leaf roll section explants with shooting media $7.5 \mathrm{mg} / 1 \mathrm{NAA}+0.5 \mathrm{mg} / \mathrm{l} \mathrm{Kn}$ of variety Isd 35 . But shoot length per explant was found highest in leaf segment explants with shooting media $7.5 \mathrm{mg} / \mathrm{l} \mathrm{NAA}+0.5 \mathrm{mg} / \mathrm{l} \mathrm{Kn}$ of variety Isd 35 . The highest rate of shoot multiplication was observed in the variety Isd 35 with shooting media $1.0 \mathrm{mg} / \mathrm{l} \mathrm{BAP}+0.5 \mathrm{mg} / \mathrm{Kn}$. The lowest days to root initiation was found in variety Isd 35 with $5.0 \mathrm{mg} / \mathrm{l} \mathrm{NAA}$. The number of roots and root length per shoot was also found highest in variety Isd 35 with $5.0 \mathrm{mg} / \mathrm{l} \mathrm{NAA}$. 


\section{Acknowledgements}

The author expressed his heartfelt gratitude to all the members of Biotechnology Division of Bangladesh Sugarcrop Research Institute for their cordial help, inspiration and moral support. The author also expressed his heartiest gratitude to all co-authors for their guidance, encouragement and constructive suggestions during the whole period of this research work.

\section{References}

[1] Cheema KL and Hussain M (2004) Micropropagation of sugarcane through apical bud and axillary bud. International Journal of Agriculture and Biology 6(2), 257-259.

[2] Gill R, Malhotra PK and Gosal SS (2006) direct plant regeneration from cultured young leaf segments of sugarcane. Plant Cell, Tissue and Organ Culture 84, 227-231. https://doi.org/10.1007/s11240-005-9015-9.

[3] Gupta PK and Bhatia A (2004) Induction of efficient and reproducible plant regeneration from tissue cultures of some Indian popular sugarcane varieties. 5th International Plant Tissue Culture \& Biotech Conference. 4-6 December, Dhaka, Bangladesh, 17.

[4] Ramon MC and Federico CB (2002) Seed Cane Production for the Philippine Sugar Industry. Philippine Sugar Research Institute (PHILSURIN), Philippines.

[5] Shukla R, Khan AQ and Garg GK (1994) In vitro clonal propagation of sugarcane: optimization of media and hardening of plants. Indian Sugar May 1994, 113-116.

[6] Singh B, Yadav GC and Lal M (2001) an efficient protocol for micropropagation of sugarcane using shoot tip explants. Sugar Tech 3(3), 113-116. https://doi.org/10.1007/BF03014574.

[7] Sood N, Gupta PK, Srivastava RK and Gosal SS (2006) Comparative studies on field performance of micro propagated and conventionally propagated sugarcane plants. Plant Tissue Culture \& Biotechnology 16(1), 25-29. https://doi.org/10.3329/ptcb.v16i1.1102.

[8] Tarique HM, Mannan MA, Bhuiyan MSR and Rahaman MM (2010) Micropropagation of sugarcane through leaf sheath culture. International Journal of Sustainable Crop Production 5(2), 13-15. 